\title{
The Use of Dramatic Theater in BIPA (Bahasa Indonesia untuk Penutur Asing) Classes: A Case in Petra Christian University, Surabaya, Indonesia
}

\author{
Ribut Basuki* and Meilinda Meilinda \\ Faculty of Language and Literature, Petra Christian University, 121-131 Siwalankerto, \\ Surabaya 60236, Indonesia
}

\begin{abstract}
The teaching-learning techniques of BIPA (Bahasa Indonesia untuk Penutur Asing - Indonesian for Speakers of Other Languages) for language skills are oftentimes separated from that of 'cultural' skills. Even worse, BIPA teachers tend to devote only a little attention to students' cultural sensitivity. Dramatic Theatre, when used appropriately, offers engaging techniques for the teaching-learning of both language and cultural skills. Dramatic theatre's 'production process' is very useful in developing linguistic and cultural sensitivities to the students. The teaching-learning of BIPA using the Dramatic Theatre production process at Petra Christian University, Surabaya, Indonesia has shown that it is a promising teachnique to be developed and implemented. The students' involvement in the process from the preparations, rehearsals, and finally performance gives them a chance to enjoy and, especially, learn the Indonesian linguistic as well as cultural nuances more or less authentically. This paper is an evaluation of BIPA through dramatic theatre at PCU. It will show how students are involved in the production process, learn Bahasa Indonesia, and grasp Indonesian culture both from the play they perform and the process of production itself. It finally gives evaluation and recomendation for further use of dramatic theatre for BIPA at PCU.
\end{abstract}

Keywords: Teaching-learning technique, dramatic theatre, performance, language, culture.

\section{Introduction}

The teaching-learning of BIPA at Petra Christian University (PCU), Surabaya, was initiated in the early 2000s when the Dean of the Faculty of Letters introduced it to the teachers of the English Department. However, the full implementation started only in the 2010s when the Indonesian Government introduced Dharmasiswa Scholarship, a scholarship for foreign students to study in Indonesia to learn, among others, Bahasa Indonesia. The Indonesian government realizes that Bahasa Indonesia is not an international language. On the other hand, the Indonesian government believes that cultural and language penetrations are needed to introduce Indonesia to the world. Therefore, they offer 750 scholarships per year for international students who would like to learn the Indonesian language and culture.

* Corresponding author: rbasuki@petra.ac.id 
PCU is one of the universities appointed to host these international students. The students who have come to PCU are in general from European countries like Holland, Poland, Slovakia, and Lithuania.

Since its implementation in 2010, BIPA (Bahasa Indonesia untuk Penutur Asing/Indonesian for Speakers of Other Languages) administrators, as well as teachers, have found out that Dharmasiswa students are in general older and more mature compared to regular undergraduate students in Indonesia. Some of them even hold a Master's degree. Paying attention to their characteristics, BIPA at PCU tried to explore different teachinglearning techniques to cater to the students' needs. On the other hand, the English Department of PCU has been doing TEFL (Teaching English as a Foreign Language) using the dramatic theatre. In the English Department, students learn dramatic theatre including acting, directing, and theatre production while they are learning English. This is because the faculty believes that, as Miccoli [1] puts it, "Learning language cannot be divorced from culture learning." By learning to produce a play as a cultural product, it is expected that students learn the language better. Therefore, teaching and learning of BIPA through dramatic theatre has been a natural option for some instructors at the English Department, PCU. When BIPA through dramatic theatre was offered in the second semester of 2013, four students were determined to take it. This paper is more or less an action research report of BIPA through dramatic theatre taken by those four students, its evaluation, and some suggestions for future implementations. Although after 2013, there has not yet been another class using dramatic theatre for BIPA due to limited enrolment to the class, this teachinglearning is prepared with better insights once another class is opened. It is right there waiting.

\section{The teaching-learning of BIPA using dramatic theatre at Petra Christian University}

The teaching-learning process of BIPA using dramatic theatre at PCU stems from the teachers' experience in the method used for English Language Teaching (ELT). ELT using dramatic theatre at PCU has been developed since the early 2000s when students of drama classes were given a chance to stage plays they learned. Up to the present, ELT at PCU through dramatic theatre is done gradually from the first semester to the final (8th) semester. Students are introduced to the basics of theatre, especially in acting and production. Since the ELT students are fresh highschool graduates, the teachers guide them step by step in learning dramatic theatre and English at the same time. When offered to implement dramatic theatre for BIPA students, some teachers agreed to give it a try. However, for BIPA, given more limited time and more adult students, the team decided that the teacher did not need to guide them strictly.

The teacher's role was to facilitate and motivate students to be more self-directed learners. Students were encouraged to ask questions and to find out the answers through research. For this role, in her report, a teacher wrote as follows:

"It does not mean that I let them do everything without my guidance, but I gave guidance only when they required them. My relationship with my students was a partnership. It was always important to let them believe and think that it was their story, their work. In order to achieve the goal of the class, I had to set a safe and trustworthy environment that encouraged the students to ask and explore things concerning the class' project."

The team was aware that they dealt with adults; therefore, they gave the students the freedom to explore. However, they were prepared when the students came with questions. In the first meeting, the team gave the students the Basic Course Outline which showed the plan for the students' activities for the semester. In general, the plan was as the following: 
Table 1. Course outline

\begin{tabular}{|l|l|}
\hline \multicolumn{1}{|c|}{ Meetings } & \multicolumn{1}{c|}{ Activities } \\
\hline 1 to 7 & $\begin{array}{l}\text { Introduction } \\
\text { Explanation of Course Outline } \\
\text { Acting Exercises } \\
\text { Research' on Local Folklores } \\
\text { Play-Script Writing }\end{array}$ \\
\hline 8 & Midterm: Submission of Play Script \\
\hline 9 to 15 & Preparation And Rehearsals \\
\hline 16 & Final: Performance \\
\hline
\end{tabular}

Meetings 1 to 7 were devoted to the pre-production process for the learning of BIPA, playwriting, and acting/theatre skills. By the midterm (meeting 8), students were expected to master the basics of acting and finish their play script so that they were able to embark on the production process (meetings 9 to 16).

With such a course outline, the whole 16-wk class meetings was more or less a theatre production process. In the first half of the semester, the students were given an introduction to Indonesia theatre and the task of researching Indonesian folklores. By knowing and understanding the history of Indonesia theatre, the students were expected to know how to develop a script in Bahasa Indonesia. In the first meeting, it was agreed that students would perform an Indonesia folklore with a script they developed themselves. Indonesian folklores are usually written stories derived from oral tradition. Students are usually written in the form of narration, therefore, if anyone wants to perfom them for the stage, s/he has to write his/her own script. Otherwise, it should be performed with full improvisation. Since it was impossible to make them perform the stories in improvisations, it was decided that they wrote the script first. In this process, the teacher's role was needed not only as a facilitator but also as a motivator. The teacher reported what she did as follows:

Their opinions were slightly changed after teacher explained the Basic Course Outline, which shows in detail the steps that students would take in order to finish the project. Teacher revealed to them that students would get a chance to learn folklores in Indonesian culture, to use the basic acting methods, to understand how Indonesian cultural products may have similarities with their own, to believe that the piece they would make would be useful for them despite the uncomfortable process.

In fact, students finally decided to perform Bawang Merah, Bawang Putih, which is quite similar to a folk tale they were familiar with, Cinderella. By studying this tale, they, in the end, learned that there are similar folklores accross cultures. Moreover, to Dewi "tales, ..., transform people." [2]. It was expected that they created new insights with their version of Bawang Merah, Bawang Putih for Indonesian viewers. Cross-cultural perspective as such has been reported to be effective in the teaching and learning of BIPA [3]. This related to the idea that language creates culture and culture influences language [4], thus by understanding Indonesian culture through local folklore students will learn BIPA more effectively.

In the script writing process, grammar and vocabulary were taught indirectly. Students decided to start by drafting in English, and then they learned to write in Bahasa Indonesia, where they would pick vocabulary and grammar with the help of the teachers. It should be noted, however, that the script was not a direct translation from English to Bahasa Indonesia. The script functioned as a draft for the Bahasa Indonesia script they were developing. This process was also used to facilitate them in learning pronunciation and 
intonation, especially of new vocabularies employed for the script. When necessary, the students were drilled to pronounce words to build their confidence in delivering them on the stage.

In the writing process, the students also did some research to find out the most suitable underlying theme for their play. This was done with the believe that the process of making theatre will allow students to observe and find the complexity of life in the characters [5]. As they brought their research to the class, discussions were inevitable since everybody came up with different ideas. To build the theme, they came up with issues such as super power, magic, curse, mother-daughter relationship, cruelty among step sisters, power and control of knowledge, the relation between strength and size, and many more. They needed to find a theme that was appealing to the audience. After all, "theatre must first entertain if it is to appeal the audience" [6]. They also need to understand the elements of sight, sound and time when writing they play [7]. The class was also encouraged with the idea that "new play workshops are fun, exciting, often surprising, sometimes overwhelming" [8]. In the end, the class decided that they would develop the issue of step-family and woman power.

While the students were developing the script, they were also taught to understand and practice the basics of acting skills. Although they are not professional actors, they need to learn basic acting skills or techniques since "some mastery of techniques does facilitate the process" [9]. The basics of acting skills taught to them are, first of all, GOTE, which stands for Goal, Obstacle, Tactic, and Expectation [10]. It is a Stanislavkian approach to acting, which has been developed and used worldwide. By understading GOTE, as actors, students were prepared to become characters on stage. However, the teacher reported,

There were a lot of questions regarding this method. They were still afraid of exploring the possibilities. They were afraid to make mistakes. This was when physical exercises took place, where they were given acting exercises to build trust among them and to help them feel comfortable on stage.

Beside the concept of GOTE, the students were also asked to write a character analysis that would help them understand the character they were playing. With their limited skill in writing in Bahasa Indonesia, however, it was finally decided that they write the character analysis in English.

In the following meetings, while learning to act in Bahasa Indonesia, the students started to learn the cultural contents of the play. This was the time when they gradually examined and found similarities between Bawang Merah, Bawang Putih as folklore from Indonesia and that from their own countries. The practice of comparing Bawang Merah, Bawang Putih and Cinderella helped them understand Indonesian culture, which in the end help them perform more confidently.

After the midterm period, in week $9^{\text {th }}$, the students prepared for the performance. This was where they needed to rehearse a lot. The rehearsals were geared to enable them to act on stage and to say the lines they wrote in the script. This was where the teacher's function shifted from being a facilitator to being the director of the performance. The teacher reported as follows:

"We staged them on the stage, discussed the reasons why it was important for the students to move to this direction, and discussed their GOTE as a reason why they chose to act in a certain way on the stage and so on. Along the way, I helped them with memorization, pronunciation drilling, and intonation."

The rehearsal process was also a place where students learn not only Bahasa Indonesia but also the cultural nuances of Bahasa Indonesia. It involved, for example, how a step daughter behaves in front of a step mother in the story of Bawang Merah, Bawang Putih. Apart from the cultural nuances related to the play, BIPA students also mingled with local students so that they could befriend one another and learned the cultural nuances of the 
local students. As the rehearsals finally came to the dress rehearsal and final performance, it was discovered that some students were not able to really memorize their lines. It was therefore decided that the performance was done in a 'stage reading,' where students acted on stage while bringing the script. Even so, the team considered that it was a success as reported by the teacher that "as a staged reading it ran well, they were more confident, and the audience enjoyed the performance." When asked about his experience, Tomas Hancel, a Slovakian student, as reported by the teacher said,

"It is helpful because you (the student) are putting together words and emotions, so the words are not unknown sounds going out from your (the student's) mouth. Also, the performance is making it easier to sense the meanings of the words."

Thus, despite the drawbacks they found, learning BIPA through dramatic theatre was a good experience both for the teachers and students.

\section{Evaluation and recommendation}

As it has been mentioned, using Dramatic Theater in a BIPA class at Petra Christian University was more or less a try-out. Therefore, if this approach is to be implemented in the future, an evaluation from the try-out and a well prepared program needs to be done.

\subsection{Evaluation}

Teaching and learning of BIPA using dramatic theatre, as it was reported by the teachers and students, was fun as well as challenging. Students were reported to learn BIPA and theatre a lot and to enjoy the process. However, it was found out, too, that at some points, the students were also overwhelmed by the tasks they had to do. It was because they had to learn and perform more than they could handle. From the try-out, it should be noted that BIPA students actually had to learn two lessons at the same time: BIPA and Theatre. Within the two lessons, they had to learn three elements: cultural knowledge, academic knowledge, and skills.

Table 2. Teaching learning materials

\begin{tabular}{|l|l|l|l|}
\hline & \multicolumn{1}{|c|}{ Cultural Knowledge } & \multicolumn{1}{c|}{ Academic Knowledge } & \multicolumn{1}{c|}{ Skills } \\
\hline BIPA & $\begin{array}{l}\text { Indonesian cultural in } \\
\text { general }\end{array}$ & $\begin{array}{l}\text { BIPA knowledge (grammar, } \\
\text { vocabulary, etc.) }\end{array}$ & $\begin{array}{l}\text { Speaking, } \\
\text { Listening, } \\
\text { Reading, } \\
\text { Writing. }\end{array}$ \\
\hline THEATRE & Theatre-related culture & Theatre knowledge & $\begin{array}{l}\text { Acting, } \\
\text { Playwriting, } \\
\text { Theatre Production, } \\
\text { etc. }\end{array}$ \\
\hline
\end{tabular}

Thus, BIPA students, first of all, had to learn Indonesian culture, BIPA knowledge (grammar, vocabulary, intonation, etc.) and BIPA skills (Speaking, Listening, Reading, and Writing). At the same time, they had to perform on stage, and thus, they also had to learn about theatre-related cultural knowledge, the background knowledge of the theatre, and the skills of acting, playwriting, and theatre production.

From the try-out, it was discovered that there were things that worked and did not. First of all, the things that really worked were as follows:

i. The production process, especially the rehearsals, gave students a chance to practice their pronunciation and develop their vocabulary. In the process of cold reading, stage reading, and rehearsal, they had to learn to pronounce the words of the characters they were playing. Since they had to pronounce the words times and again without being repetitive (since it was how to be the characters that they needed to pay attention to), 
they finally improved their pronunciation. More than just learning new words from what they had to say as characters, they also undertood words better since as 'actors,' they needed to give emotion when saying them. They needed to understand what the words really meant with the given circumstances of the characters. Therefore, students learned pronunctiation and vocabulary effectively in BIPA through dramatic theatre.

ii. The production process also, of course, made them learn the basics of acting and play production. Being students with no background in theatre, they finally learned how to act on stage and how to create a performance.

iii. Being in BIPA through dramatic theatre also made them learn more about Indonesia culture since they had to perform 'Indonesian characters' with their cultural backgrounds. Even more, since they were asked to write a script, they had to do a kind of research about Indonesian folklores, which, of course, made them exposed to the local cultures.

There were some other things that worked, like the rapport they built with the teachers and local students, but the three mentioned above were obvious points that really worked. On the other hand, given the level of students' BIPA skills and the time frame, it was discovered that several aspects did not work as expected.

i. The process of writing the script turned out to be too hard for them, so that they needed a lot of help from the teachers. Most of the time, they failed to write grammatical sentences.

ii. The process which was set up for a real production fell short of staging reading. Although, as a staged reading, it was considered a success, the choice showed that they were not confident enough to perform in full production since they said they could not memorize their lines.

From the aspects that did not work, it could be concluded that the students' BIPA skills were still insufficient, especially in writing. Therefore, if the drama theatre approach should be used in the future, the BIPA team of PCU needs to be reformulated.

Given the level of BIPA of the students, PCU usually gets (upper beginner to lower intermediate), for the next BIPA through dramatic theatre, the administrators should consider the following:

i. Playwriting should not be given to upper beginners to lower intermediates since it will be too early for them. Instead, the teachers should provide a script. The script does not have to be 'heavily cultural' such as that on folkfore, but it could be about the everyday life of Indonesian people. The script will, at the same time, be a reading comprehension material so that while cold reading, students learn main ideas, vocabulary, grammar, etc.

ii. With a two-semester program of BIPA at PCU, in the first semester, the students may be given the basics of acting in which they learn acting with minimum words and perform short skits. After students are familiar with the basics of acting in Bahasa Indonesia, students may then embark on the production of a short play.

iii. Only when the students are of the upper intermediate and advanced levels will they be given the task of short-play writing in the first semester. For lower intermediate students, the task of writing a simple character analysis would be challenging enough.

Some other aspects should also be considered, for instance, about the fact that it is also challenging for the teachers. With better preparations and program, when this approach is implemented again in the future, it may be expected that it will be more sucessful. 


\section{Conclusion}

Just as the English Department has been doing since 2010, dramatic theatre can be an effective tool for teaching and learning a foreign language. As it has been succesful with English Language Learning at PCU, it can surely be sucessful with BIPA or the teaching of any foreign language. The class, for sure, will be demanding and challenging both for students and teachers alike. More than that, students will learn the language enjoyably, as long as the tasks are suitable for their level. This approach can be used as an alternative to the conventional teaching-learning process. The two approches, conventional BIPA and BIPA through dramatic theatre, may be given in the same semester to the same students. With the conventional BIPA, the students will experience an academic BIPA. Students may learn anyting cultural in this kind of class, yet what they learn would usually be day to day cultural experience. With BIPA through dramatic theatre, the students will experience the culture more or less artisticly. They will learn and experience acting in Bahasa Indonesia which will give them an experience they will never forget.

\section{References}

1. L. Miccoli, English Through Drama for Oral Skills Development. ELT Journal, Vol. 52. Oxford: Oxford University Press (2003). https://pdfs.semanticscholar.org/bf40/9c40837a22e20ab17c0b7cc5f6a50ed3e2b9.pdf

2. N. Dewi, K@ta a biannual publication on the study of language and literature. 19,1:32-39(2017). https://doi.org/10.9744/kata.19.1.39-46

3. Bundhowi, Paket Lintas Budaya: Perspektif Budaya dan Studi ke Indonesiaan dalam BIPA. [Cross Cultural Package: Cultural Perspectives and Study in Indonesia in BIPA]. Denpasar: APBIPA Bali (2013). [in Bahasa Indonesia]. [Online Unpublished].

4. S.W. Sarwono, Psikologi Lintas Budaya. [Cross-Cultural Psychology]. Jakarta: RajaGrafindo Persada (2016). http://www.rajagrafindo.co.id/produk/psikologi-lintasbudaya/

5. M.E. Hampton, Voices from life: The dialect life study and everyday life performance. In: Perspectives on Teaching Theatre, R. Smith. (Ed), New York: Peter Lang Publishing, Inc (2001). https://www.peterlang.com/view/product/68487?format=PBK

6. L.E. Catron, The Director's Vision: Play Direction from Pay analysis to Production. Mountain View, CA: Mayfield (1989). https://www.amazon.com/Directors-VisionDirection-Analysis-Production/dp/1577666763

7. J. Patterson, Stage Directing: The First Experiences. Boston: Pearson Education Inc (2004).

https://www.amazon.com/Stage-Directing-Experiences-JimPatterson/dp/1478615400

8. M. Kinghorn, Playwrights' best advantage: pointers for preparing for workshop, [Online] from: https://pwcenter.org/playwriting-toolkit/playwrights-bestadvantage-pointers-preparing-workshop (n.d.).

9. D. Carter, The Art of Acting. Harpenden, Herts: Kamera Books (2010). https://www.amazon.com/Art-Acting-Master-Creative-Essentials/dp/1842432214

10. R. Cohen, Acting One/Acting Two. Boston: McGraw Hill Book Company (2008). https://www.amazon.com/Acting-One-Robert-Cohen/dp/0073514160 